\title{
Biliary Reconstruction Outcome in Living Donor Liver Transplant
}

\author{
Mohammed Niyazi Gheni ${ }^{1 *}$, Tayeb Sabir Kareem² and Assad Abidon Hassoun ${ }^{3}$ \\ ${ }^{1}$ Candidate of Digestive surgery in Kurdistan board for medical specialties, Rizgary Teaching, Hospital, Zheen International Hospital, Iraq \\ ${ }^{2}$ Program director of Digestive surgery in Kurdistan board for medical specialties, Rizgary Teaching Hospital, Iraq \\ ${ }^{3}$ Research supervisor; General surgery \& organ transplant surgeon, MD, FACS, CPMC San Francisco, CA 94115, Zheen International Hospital, Iraq
}

Submission: March 06, 2018; Published: March 22, 2018

"Corresponding author: Mohammed Niyazi Gheni, Candidate of Digestive surgery in Kurdistan board for medical specialties, Rizgary Teaching, Hospital, Zheen International Hospital, Iraq, Email: mohammedprof4@gmail.com

\begin{abstract}
Background \& objectives: Biliary tract complications remain one of the most serious morbidities following liver transplantation. A series of studies has been carried out to compare different techniques in liver transplant but most of them were in the way of progress new operative technique and treatment. The purpose of this study was to compare outcomes of different techniques used for biliary reconstruction in living donor liver transplantation.
\end{abstract}

Methods: Between December 2010 and July 2017, 25 patients reviewed and had received right or Left lobe living donor liver transplant. Biliary reconstruction was achieved with Duct to Duct anastamosis in $80 \%(\mathrm{n}=20)$ and Roux en-Y hepaticojejunostomy in 20\% (n=5). The graft lobe, number of graft bile duct, technique of anastomosis, incidence and management of biliary complications were reviewed in the follow up period 6 month to 7 year.

Results: The incidence of biliary complications was $12 \%$; two out of 5 for Roux-en-Y hepaticojejunostomy, from liver cut surface and the other from the site of hepaticojejunostomy, both treated by abdominal wash out and control of infection. The third bile leak out of 20 duct-toduct reconstruction, due to sphincter of oddi dysfunction treated by Endoscopic retrograde cholangio pancreatography sphincterotomy, and there was no stricture neither Roux en-Y nor duct to duct reconstruction.

Conclusion: Overall complication rate was low $12 \%$ and the number of cases was very small to withdraw statistical significance conclusion, however 2 out of 5 biliary complications happen after Roux en-Y versus 1 out of 20 with duct to duct reconstruction.

Keywords: Live donor liver transplant; biliary tract; duct to duct anastomosis

Abbreviation: LDLT: Living Donor Liver Transplant; RYHJ: Roux en -Y HepaticoJejunostomy; DD:Duct to Duct; PDS: Polydioxanone Suture; OLTx: Orthotropic Liver Transplantation; MELD: Model for End Stage Liver disease; GIA: Stappler GastroIntestinal Anastomosis stappler

\section{Introduction}

Orthotropic liver transplantation (OLTx) including live donor liver transplantation is the only live saving treatment for many patients with end stage liver disease; including cirrhosis, hepatocellular carcinoma and acute liver failure.

The 'Achilles' heel' of liver transplantation is bile duct reconstruction [1]. Although there are progress in reconstruction techniques, organ preservation and immunosuppressive management, biliary complications still significantly high (729\%). Biliary complications are higher with Living donor liver transplant (LDLT) than whole organ liver Transplant [2]. Biliary leaks and strictures are the most common biliary complications which could be caused by ischemia, infection, immunological or technical factors. Other factors such as; sphincter of Oddi dysfunction, hemobilia, and biliary obstruction from cystic duct mucocele, stones, sludge or casts have also been observed as other potential causes $[3,4]$.

The major concern in LDLT is arterial supply for biliary anastomosis. A study showed that arterial supply for the bile duct comes caudally through periduodenal arteries in $60 \%$, from the cranial side in $38 \%$ and only $2 \%$ from the hepatic artery itself. The 3 o'clock, 9 o'clock, and retroportal arteries give rise to multiple arteriolar branches, which form a free anastomosis within the wall of the bile duct [5], so during dissection several principles should be followed to obtain a healthy wellvascularized bile duct, as minimizing dissection at the hilar plate to avoid microcirculation disruption around the hepatic duct and artery, and dividing the duct sharply and perpendicularly to its 
long axis to minimize skeletonization of bile duct which directly affect success of anastamosis. There are two main types of bile leak after LDLT anastomotic leaks, and cut surface leaks [6]. Anastomotic leaks are the more common type and occur more frequently with Roux-en-Y anastomosis than with duct to duct anastomosis [7]. Cut surface bile leaks usually originate from small bile ducts in the caudate lobe that are transected during surgery and are usually detected incidentally at reoperation [8].

In Living donor liver transplant, different techniques has been practiced including; duct-to-duct reconstruction, Roux-en-Y hepaticojejunostomy, and/ or combination. Ductto-duct is currently our standard technique of choice for bile duct reconstruction in LDLT for many foreseeable advantages including; its physiologic bilioenteric continuity and easy accessibility via ERCP as well as preventing reflux ascending cholangitis $[9,10]$. We here by review our cases retrospectively in term of complexicity, selection of left versus right lobe, number of ducts, and various reconstruction techniques and discuss outcome.

\section{Materials and Methods}

\section{Study design}

This study is a case recorded study on a 25 patient (both pediatric $=6$ and adults $=19$ ) who had liver cirrhosis or liver failure and undergone LDLT at Zheen International Hospital from December 2010 and July 2017. Patients that die within less than 3 month of liver transplant or incomplete data are excluded from this study. We specifically looked for patient's case sheet records of age, cause of liver cirrhosis or failure and Model for End Stage Liver disease (MELD score), liver lobe side, number of duct, and technique of reconstruction of bile duct; roux en-Y versus duct to duct.

\section{Immune suppression drugs}

a) Solumedrol gm intraoperatively at the anhepatic phase, 2nd dose given on arrival to intensive care unit then tapered daily $(500,200,80,40)$ and on $20 \mathrm{mg}$ in the first week and $10 \mathrm{mg} 2 \mathrm{nd}$ week and maintain on $5 \mathrm{mg}$ according liver state about rejection, mostly given for 6 month and stop gradually.

b) Mycophenolate mofetil acid (cellcept): given next morning, 1gm twice daily, for first 6 month of transplant.

c) Tacrolimus: restrict first 3 day post operation, and start with low dose $0,5 \mathrm{mg}$ twice daily and increase to make tacrolimus level between 8 to 10 .

The graft lobe, number of bile duct, type of anastomosis, technique of anastomosis, and management of biliary complications were analyzed. This study has been approved by the ethical committee of Kurdistan Board for Medical Specialties and access of data done after taking permission from Zheen International Hospital manager.

\section{Results}

Of 25 patients with biliary reconstruction; the recipient characters demography shown in Table 1 and donor characters demography shown in Table 2, duct to duct was performed in $80 \%(n=20)$ and Roux en $Y$ in $20 \%(n=5)$ as shown in Table $3 \& 4$.

Table 1: Recipient characters demography.

\begin{tabular}{|c|c|c|c|c|}
\hline & Number & Age (year) & male & Female \\
\hline pediatric & $24 \%(n=6)$ & $\begin{array}{c}1.1 \\
14\end{array}$ & $\begin{array}{c}20 \% \\
(n=5)\end{array}$ & $4 \%(n=1)$ \\
\hline Adult & $76 \%(n=19)$ & $16-65$ & $\begin{array}{c}60 \% \\
(n=15)\end{array}$ & $16 \%(n=4)$ \\
\hline \multicolumn{5}{|c|}{ Disease } \\
\hline NASH & $20 \%(n=5)$ & $39-65$ & $\begin{array}{c}12 \% \\
(n=3)\end{array}$ & $8 \%(n=2)$ \\
\hline Wilson & $20 \%(n=5)$ & $9-17$ & $\begin{array}{c}20 \% \\
(n=5)\end{array}$ & \\
\hline HBV & $12 \%(n=3)$ & $42-54$ & $\begin{array}{c}12 \% \\
(n=3)\end{array}$ & \\
\hline Alcoholic & $12 \%(n=3)$ & $31-47$ & $\begin{array}{c}12 \% \\
(n=3)\end{array}$ & \\
\hline AlH & $12 \%(n=3)$ & $19-25$ & $8 \%(n=2)$ & $4 \%(n=1)$ \\
\hline $\begin{array}{c}\text { Glycogen } \\
\text { storage }\end{array}$ & $8 \%(n=2)$ & $2-7$ & $4 \%(n=1)$ & $4 \%(n=1)$ \\
\hline HCV & $4 \%(n=1)$ & 59 & $4 \%(n=1)$ & \\
\hline HAV & $4 \%(n=1)$ & 1.1 & $4 \%(n=1)$ & \\
\hline Cholangitis & $4 \%(n=1)$ & 24 & $4 \%(n=1)$ & \\
\hline Caroli & $4 \%(n=1)$ & 32 & $4 \%(n=1)$ & \\
\hline MELD score & $9-43$ & & & \\
\hline
\end{tabular}

Table 2: Donor characters demography.

\begin{tabular}{|c|c|c|l|c|c|}
\hline & Number & $\begin{array}{c}\text { Age } \\
\text { (year) }\end{array}$ & Single duct & $\begin{array}{c}\text { Two } \\
\text { duct }\end{array}$ & $\begin{array}{c}\text { Triple } \\
\text { duct }\end{array}$ \\
\hline $\begin{array}{c}\text { Right } \\
\text { lobe }\end{array}$ & 13 & $18-45$ & $32 \%(n=8)$ & $\begin{array}{c}16 \% \\
(n=4)\end{array}$ & $4 \%(n=1)$ \\
\hline $\begin{array}{c}\text { Left } \\
\text { lobe }\end{array}$ & 12 & $19-42$ & $44 \%(n=11)$ & $\begin{array}{c}14 \% \\
(n=1)\end{array}$ & \\
\hline
\end{tabular}

Table 3A: Duct to duct reconstruction $(n=20)$.

\begin{tabular}{|c|c|c|c|}
\hline & Duct to duct & Bile leak & $\begin{array}{c}\text { Biliary } \\
\text { stricture }\end{array}$ \\
\hline Right lobe & $44 \%(n=11)$ & 0 & 0 \\
\hline Left lobe & $36 \%(n=9)$ & $4 \%(n=1)$ & 0 \\
\hline Total & $80 \%(n=20)$ & $4 \%(n=1)$ & 0 \\
\hline
\end{tabular}

Table 3B: Roux en-Y reconstruction ( $n=5)$.

Table 3: Frequency distribution of reconstruction and complication.

\begin{tabular}{|c|c|c|c|}
\hline & Roux en-Y & Bile leak & Biliary stricture \\
\hline Right lobe & $8 \%(\mathrm{n}=2)$ & $2(8 \%)$ & 0 \\
\hline Left lobe & $12 \%(\mathrm{n}=3)$ & 0 & 0 \\
\hline Total & $20 \%(\mathrm{n}=5)$ & $2(8 \%)$ & 0 \\
\hline
\end{tabular}


Table 4: Frequency distribution of duct and reconstruction by types of duct and number.

\begin{tabular}{|c|c|c|c|c|}
\hline & $\begin{array}{c}\text { Duct to } \\
\text { duct }\end{array}$ & Roux en-Y & Bile leak & $\begin{array}{c}\text { Biliary } \\
\text { stricture }\end{array}$ \\
\hline Single duct & $56 \%(n=14)$ & $20 \%(n=5)$ & $12 \%(n=3)$ & 0 \\
\hline Two duct & $20 \%(n=5)$ & 0 & 0 & 0 \\
\hline Triple duct & $4 \%(n=1)$ & 0 & 0 & 0 \\
\hline
\end{tabular}

The operative techniques:

A. Donor liver lobe resection: After full investigation of donor preoperatively, intraoperatively cholangiography done for all donor before starting liver resection to delineate the bile duct anatomy and post resection for any bile leak from remaining liver lobe.

B. Duct to duct reconstruction: Biliary reconstruction achieved with Duct to Duct anastamosis in 80\% (20 patients) in whom the common hepatic duct on the native side not affected by chronic liver disease and match the size of the duct of graft, duct to duct anastamosis was done with a running 6-0 PDS suture on the posterior wall, and interrupted 6-0 PDS suture anteriorly.

C. Roux-en-Y reconstruction: Roux-en-Y hepaticojejunostomy reconstruction done in 20\% (5 patients) where the common bile duct on the native side show significant inflammation or adhesion to the portal vein and in it was impossible to use for the biliary reconstruction. The jejunum about $30 \mathrm{~cm}$ from the ligament of Treitz was divided with Gastro Intestinal Anastomosis (GIA) stapler. Roux limb of jejunum which was advanced through the right meso colonic avascular window toward the hilum of liver graft, enterotomy was made to match the size of graft hepatic duct about $1 \mathrm{~cm}$ and hepaticojejunostomywas performed with a running 6-0 PDS suture posteriorly and interrupted 6-0 PDS suture anteriorly leaving a segment of size 5 pediatric feeding tube as stent that was secured through the enterotomy with a U stitch 6-0 PDS sutures, the roux limb was measured for about $40 \mathrm{~cm}$ before it was connected with the proximal end of the jejunum which was done with a GIA stapler. In both 2 drain was put one under diaphragm and cut surface of liver, and the second under the site of anastamosis (duct to duct or hepaticojejunostomy).

The overall incidence of bile leak 12\% ( $n=3)$; two recipient out of 5 with Roux-en-Y hepaticojejunostomy, both of them was right liver lobe and single duct, diagnosed by increase in drain output and changing color from serous to bile color at day 10 to 15 , one of this recipient the leak was from liver cut surface and the other from the site of hepaticojejunostomy due to intraabdominal infection, not responding to conservative measurement, both treated by abdominal wash out and good drainage plus control of infection.

The third recipient bile leak out of 20 recipient with ductto-duct reconstruction, which was left liver lobe and single duct, the condition start 2 week post operation as jaundice and ultra sound show collection around liver and not respond to drainage under ultrasound guide and become febrile and pleural effusion, so operative washout done which show leak from the site of anastomosis and dilated distal and proximal bile duct, postoperative Endoscopic retrograde cholangio pancreatography (ERCP) arranged which show sphincter of oddi dysfunction treated by sphincterotomy, and there was no incidence of stricture neither Roux en-Y nor duct to duct Biliary reconstruction during follow up by liver function test.

There were no differences between the patient with or without biliary complication ( $n=3$ versus $n=22$, respectively) in MELD score (12 - 23 versus 9 - 43); or recipient age (2 - 32 years versus 1.1 - 65 years); and number of duct. Overall incidence of biliary leakage were $8 \%$ and stricture $0 \%$ in Roux-en-Y $(n=5)$, for duct-to-duct $(n=20)$ incidence of bile leak and stricture was $4 \%$ and $0 \%$ respectively. There was a high incidence of biliary complications in the right lobe liver graft, single duct with Roux en-Y reconstruction than duct to duct anastamosis.

\section{Discussion}

The incidence of biliary complications in LDLT has been reported to range from $15 \%$ to $40 \%$ [11-17]. In our study the incidence of bile leak in $80 \%$ of duct to duct anastamosis was $4 \%$ and the cause was not from the site of anastamosis but from sphincter of oddi dysfunction, while in $20 \%$ Roux en-Y reconstruction incidence of leak $8 \%$ and the cause was infection in one case, infection and cut surface leak in the second case, the incidence of Biliary stricture is $0 \%$, so the overall incidence of Biliary complication is $12 \%$ which is the least in comparing with other studies like;

\begin{tabular}{|c|c|c|c|c|c|c|}
\hline Authors & Country & Year & $\begin{array}{c}\text { No. of } \\
\text { patient }\end{array}$ & $\begin{array}{c}\text { Bile } \\
\text { leak }\end{array}$ & Stricture & overall \\
\hline $\begin{array}{c}\text { Freise et al. } \\
\text { [14] }\end{array}$ & $\begin{array}{c}\text { United } \\
\text { States }\end{array}$ & 2008 & 384 & $27.2 \%$ & $18 \%$ & $35.5 \%$. \\
\hline $\begin{array}{c}\text { Shah et al. } \\
\text { [13] }\end{array}$ & Canada & 2007 & 128 & $14.8 \%$ & $17.1 \%$ & $26.0 \%$ \\
\hline $\begin{array}{c}\text { Marubashi } \\
\text { et al. [15] }\end{array}$ & Japan & 2009 & 83 & $1.2 \%$ & $7.2 \%$ & $8.4 \%$ \\
\hline $\begin{array}{c}\text { Wadhawan } \\
\text { et al. [16] }\end{array}$ & India & 2010 & 338 & $8.8 \%$ & $10.3 \%$ & $19 \%$ \\
\hline $\begin{array}{c}\text { Kim et al. } \\
\text { [17] }\end{array}$ & $\begin{array}{c}\text { South } \\
\text { Korea }\end{array}$ & 2010 & 22 & $0 \%$ & $9.1 \%$ & $9.1 \%$ \\
\hline
\end{tabular}

In Marubashi et al the incidence of bile duct stricture is high and this may be due to using tub, in our study incidence of stricture is $0 \%$, duct to duct anastamosis was done with a running 6-0 PDS suture on the posterior wall, and interrupted 6-0 PDS suture anteriorly with no use of tube. This study has several limitations. First, review of case study with a limited number of patients. Second, the patient population is heterogeneous from pediatric to adults. In conclusion, our findings showed that DD anastomosis is better than RYHJ after LDLT and provides access for future endoscopic therapy for leak or stricture. In both group no biliary strictures are found. 


\section{References}

1. Rasmussen A, Braidley P, Jamieson NV, Friend PJ, Calne RY (1994) Biliary complications in orthotopic liver transplantation. Transplant Proc 26: 1792.

2. Wojcicki M, Milkiewicz P, Silva M (2008) Biliary tract complications after liver transplantation: a review. Dig Surg 25: 245-257.

3. Stratta RJ, Wood RP, Langnas AN, Hollins RR, Bruder KJ, et al. (1989) Diagnosis and treatment of biliary tract complications after orthotopic liver transplantation. Surgery 106: 675-683.

4. Colonna JO, Shaked A, Gomes AS, Colquhoun SD, Jurim O, et al. (1992) Biliary strictures complicating liver transplantation. Ann Surg 216: 344-350.

5. Northover JM, Terblanche J (1979) A new look at the arterial supply of the bile duct in man and its surgical implications. Br J Surg 66: 379-384.

6. Gunawansa N, McCall JL, Holden A, Plank L, Munn SR (2011) Biliary complications following orthotopic liver transplantation: a 10-year audit. HPB (Oxford) 13: 391-399.

7. Gondolesi GE, Varotti G, Florman SS, Muñoz L, Fishbein TM, et al (2004) Biliary complications in 96 consecutive right lobe living donor transplant recipients. Transplantation; 77: 1842-1848.

8. Jassem W, Heaton ND, Rela M (2008) Reducing bile leak following segmental liver transplantation: understanding biliary anatomy of the caudate lobe. Am J Transplant 8: 271-274.

9. Ishiko T, Egawa H, Kasahara M, Nakamura T, Oike F, et al. (2002) Ductto-duct biliary reconstruction in living donor liver transplantation utilizing right lobe graft. Ann Surg 236: 235-240.

10. Hisatsune H, Yazumi S, Egawa H, Asada M, Hasegawa K, et al (2003). Endoscopic management of biliary strictures after duct-to-duct biliary reconstruction in right-lobe living donor liver transplantation. Transplantation 76: 810-815.

11. Kawachi S, Shimazu M, Wakabayashi G, Hoshino K, Tanabe M et al. (2002) Biliary complications in adult living donor liver transplantation with duct-to-duct hepaticocholedochostomy or Roux-en-Y hepaticojejunostomy biliary reconstruction. Surgery 132: 48056.

12. Marcos A, Ham JM, Fisher RA, Olzinski AT, Posner MP (2000) Surgical management of anatomical variations of the right lobe in living donor liver transplantation. Ann Surg; 231: 824-831.

13. Shah SA, Grant DR, McGilvray ID, Greig PD, Selzner M, et al. (2007). Biliary strictures in 130 consecutive right lobe living donor liver transplant recipients: results of a Western center. Am J Transplant 7: 161-167.

14. Freise CE, Gillespie BW, Koffron AJ, Lok AS, Pruett TL, et al (2008) Recipient morbidity after living and deceased donor liver transplantation: findings from the A2ALL Retrospective Cohort Study. Am J Transplant 8: 2569-2579.

15. Marubashi S, Dono K, Nagano H, Kobayashi S, Takeda Y, et al (2009) Biliary reconstruction in living donor liver transplantation: technical invention and risk factor analysis for anastomotic stricture. Transplantation 88: 1123-1130.

16. Wadhawan M, Kumar A, Gupta S, Goyal N, Shandil R, et al. (2013) Posttransplant biliary complications: an analysis from a predominantly living donor liver transplant center. J Gastroenterol Hepatol; 28: 10561060 .

17. Kim SH, Lee KW, Kim YK, Cho SY, Han SS, Park SJ (2010) Tailored telescopic reconstruction of the bile duct in living donor liver transplantation. Liver Transpl 16: 1069-1074.

\section{Your next submission with JuniperPublishers will reach you the below assets}

- Quality Editorial service

- Swift Peer Review

- Reprints availability

- E-prints Service

- Manuscript Podcast for convenient understanding

- Global attainment for your research

- Manuscript accessibility in different formats

( Pdf, E-pub, Full Text, audio)

- Unceasing customer service

Track the below URL for one-step submission

https://juniperpublishers.com/online-submission.php 